\title{
The Effect of Top Management Support on The Effectiveness of Public Sector Internal Audit in Indonesia with Competence and Independence as Intervening Variables
}

\author{
Kanta Rio Saputra \\ Universitas Padjadjaran \\ Email: kantariosaputra@gmail.com \\ Srihadi Winarningsih \\ Universitas Padjadjaran \\ Email: srihadi.winarningsih@unpad.ac.id \\ Evita Puspitasari \\ Universitas Padjadjaran \\ Email: evita.puspitasari@unpad.ac.id
}

\begin{abstract}
The phenomenon of corruption cases that often occur in local governments and BPK findings related to weaknesses in the internal control system indicates that the internal audit function in local governments is not yet effective. This study aims to examine and measure how much influence the factors that affect the effectiveness of the internal audit in the public sector in Indonesia. The results of this study are expected to be used as consideration for policymaking by the Government, which is currently encouraging the improvement of the effectiveness of internal audit in Indonesia. The population in this study were all internal audits of local government in Indonesia. The data collected in this study were 55 internal audits of local government throughout Indonesia. The research was conducted with a quantitative approach using SEM PLS. The results showed that independence and competence had a significant effect on the effectiveness of internal audit and top management support indirectly had a significant effect on the effectiveness of internal audit through competence and independence. However, top management support directly does not have a significant effect on the effectiveness of the internal audit. This research also revealed that with the support of top management to the competence and independence of internal audit, it will be able to encourage a more effective internal audit in carrying out its duties and functions.
\end{abstract}

Keywords: Internal Audit, Top Management Support, Competence, Independence, Effectiveness of Internal Audit

\section{Introduction}

Public sector internal audit is one of the important elements in safeguarding the accountability of government administration. Financial and development guarding is the main task of APIP which must be implemented as effectively as possible. APIP is currently considered ineffective in carrying out these two roles, based on data on the overall performance score of the local government as measured through the evaluation of the performance of local government administration or called EKPPD from the Ministry of Internal Affairs in 2018, the majority of Regional Governments are still below 3.00 with predicate high enough and low, namely $50 \%$ or 262 local government from a total of 524 local government (Ministry of Internal Affairs, 2019). The EKPPD score below 3.00 in the Regional Government shows that the performance of local government administrators has not been effective and efficient enough, so it can be concluded that the role of APIP is not yet maximized in supporting the effective and efficient implementation of the regional government.

Another phenomenon, based on audit data from the Financial Audit Agency (BPK) on 542 Regional Government Financial Reports (LKPD) in 2018, is known that there are 5,858 problems related to the internal control system. This weakness of internal control is also shown in the many corruption cases that occur in the public sector, data from the 2015-2019 KPK prosecution statistics taken from 
www.kpk.go.id shows that 596 corruption cases handled by the KPK in the 2015-2019 period occurred. within the central and local government levels.

The weaknesses related to accounting and reporting control systems and internal control systems can affect the quality of government financial reports in Indonesia so that the government should immediately improve these weaknesses by maximizing the role of effective internal audit to be able to detect and create a good internal control in each organization so that in the future there are no internal control weaknesses that could potentially lead to fraud.

There are still many BPK findings related to Internal control/SPI weaknesses and corruption cases in the public sector, indicating that the internal audit function in the public sector is not yet effective. This is supported by a statement from the Deputy Chairperson of the Corruption Eradication Commission (KPK) for the 2014-2019 period, Laode M Syarief, as quoted from www.republika.com dated 28 April 2018, which assesses that the presence of the Government Internal Supervisory Apparatus (APIP) has not been effective in preventing corruption.

Based on the review of the effectiveness of internal audit research in Indonesia, there is some of the population have been unexplored. mostly the research only focuses on a person, not an institution whereas an analysis of this institution is important because with a view of institutional we can see a whole of internal audit department problem so that with the result can recommend for improvement to make audit internals are more effective. On the other hand, there are also many results of previous research which results are still inconsistent in analyzing the factors that influence the effectiveness of internal audits, especially the factors of top management support, competence, and independence.

Apart from the 2 things above, the authors feel that the results of research related to the influence of top management support on the effectiveness of internal audit have not been discussed deeply, this can be seen from the statement of Cohen and Sayag (2010) which states that management support is important in the implementation of the internal audit because the determinants of internal audit effectiveness come from management support, namely hiring competent internal audit staff, developing internal auditors' careers, and ensuring the independence of the internal audit organization. According to the author's analysis, the statement indicates that there is a possibility that the influence of top management support is not direct to the effectiveness of internal audit, because top management support must first support the competence and independence of internal audit to make internal audit effective. on this matter, this research will examine the indirect effect of management support on the effectiveness of internal audit through competence and independence.

Based on the background that has been described and realizing the importance of the role and function of internal audit in the public sector, the authors are interested in researching with the title is The Effect of Top Management Support on the Effectiveness of Internal Audit in the Public Sector in Indonesia with Competence and Independence as Intervening Variables. The research that will be carried out by the author will be different from previous research that already exists. This is because the author will test the influence between variables down to the measuring indicators using the SEM PLS method which later can find out which indicator of each variable has a stronger influence on these latent variables so that later it can become a reference material in increasing the effectiveness of internal audit that is being encouraged. by the government. Data collection carried out in this study is not only in one internal audit but in 55 Internal Audit/APIP throughout Indonesia. With a fairly broad research scope, it is hoped that the results of the research can become a complete picture to see one of the determining factors for the effectiveness of the internal audit. Besides, this research will examine the indirect effect of management support on the effectiveness of internal audit through competence and independence. 


\section{Literature Review}

\subsection{Agency Theory}

Agency theory is a bonded relationship between agents and principals to carry out activities with the delegation of authority in making decisions given to agents (Meckling \& Jensen, 1976).

Agency theory in this study is used to see the relationship between the legislature and the executive in running the government. In the public or government context, in Indonesia, there are legislative parties, namely representatives of the people/DPR, and the executive, namely the government.

\subsection{Internal Audit}

The Indonesian Government Internal Audit Standard (2014) explains that an internal audit is an objective activity that is carried out independently and is planned to provide added value to the organization and also improve the performance of an organization (auditee). Tugiman (2006) defines an internal audit as an independent assessment function within the organization, the assessment is in the form of testing and evaluating the organization's activities carried out.

\subsection{Effectiveness of Internal Audit}

The effectiveness of internal audit refers to the capability of the internal auditors in achieving the objectives and functions of the internal audit (Badara and Saidin, 2014). Meanwhile, Cohen \& Sayag (2010) states that the effectiveness of the internal audit function is assessed by the suitability of the implementation of supervision with several general standards derived from the characteristics of the internal auditor. Salehi (2016) also explained that the effectiveness of the internal audit that must be understood is how an internal auditor plays a role effectively concerning its objectives.

The AAIPI Internal Audit Standard (2014) explains that the role and function of an effective internal audit are generated in the form of assurance activities on compliance, efficiency, effectiveness, and economy in achieving the objectives of assigning duties and functions of Government Agencies, providing early warnings on irregularities and improving functions. risk management in carrying out the duties and functions of Government Agencies. Besides, it can be in the form of providing strategic recommendations and suggestions that can maintain and enhance the quality of the implementation of duties and functions of Government Agencies as well as the quality of their governance and provide value-added to the organization.

\subsection{Top Management Support}

Top management in this study is in the form of support from top management in the public sector, namely the Regional Head of the Regional Government who oversees the internal audit. Management support or Management support is an important factor apart from audit quality to seek the effectiveness of internal audit (Yismaw et al, 2007). This is because hiring competent internal auditors, developing careers for internal auditors, and giving freedom to conclude the results of their work for internal auditors are decisions made by top management. (Cohen \& Sayag, 2010)

Management support contributes the most to the effectiveness of the internal audit. In the absence of support from management, the scope of internal audit work and internal audit resources will be limited which will make internal audits not independent (Alzeban \& Gwilliam, 2014).

\subsection{Competence}

The Indonesian Government Internal Auditor Association (2014) provides its view that competence is a characteristic or individual ability consisting of expertise, knowledge, skills, and experience.

According to The IIA Research Foundation's Common Body of Knowledge (CBOK) study (2007), competence is the ability to adequately carry out tasks and roles. Competence is formed from skills and knowledge which can also be obtained through work experience and learning processes. Competence connects knowledge, values, personal attitudes, and skills. 


\subsection{Effect of Top Management Support on the Effectiveness of Internal Audit}

In agency theory, it is explained that an agency relationship is a contract between the agent and the principal in carrying out activities by granting authority to the agent. Internal auditors themselves are part of the technical matters of principal supervision (Adams, 1994).

The existence of an internal audit is expected to help the principal so that every decision and activity of the agent is under the supervision of the principal, thus it is hoped that the delegated authority will be carried out by the direction and objectives agreed upon and declared by the principal. To function optimally, management support is needed in supporting each of its functions for internal audit. Then it can be concluded that top management support is a factor that plays a very important role in the effectiveness of the implementation of the duties of the government's internal audit.

Alzeban \& Gwilliam (2014), Mihret \& Yismaw (2007), Baharud-din et al (2014), and Drogaras et al (2015), Cohen \& Sayag, (2010) in their research concluded that management support affects the effectiveness of the internal audit.

It can be concluded that management support plays an important role and greatly influences the effectiveness of the internal audit. From this description, the research hypothesis is formulated as follows:

$\mathrm{H}_{1}$ : Top management support has a positive effect on the effectiveness of the internal audit.

\subsection{Effect of top management support on competence}

According to Cohen \& Sayag (2010), management as a policymaker has the authority to employ internal auditors with competencies that meet standards and have the right in career development, so top management should ensure the competence of internal audit. as in the AAIPI Internal Audit Standards (2014) and BPKP (2015) in the APIP capability improvement guidelines which say that there must be a commitment from stakeholders, one of which is top management to support the improvement of APIP competence.

It can be concluded that top management support has an important role in APIP's competence. From this description, the research hypothesis is formulated as follows:

$\mathrm{H}_{2}$ : Top management support has a positive effect on competence.

\subsection{Effect of top management support to independence}

The AAIPI Internal Audit Standard (2014) explains that the position of APIP must be placed appropriately so that it is free from intervention, and has adequate support from the highest leadership of the organization so that it can cooperate with auditors and carry out work freely. Management support is very influential in influencing auditor independence, citing Cohen and Sayag (2010) who say that internal auditors are given the freedom to conclude that their work is a decision made by top management. Baharud-din et al (2014) also concluded that without support from management, an internal audit would not be independent and its scope of work and resources would be limited. It can be concluded that top management support has an important role in APIP's competence. From this description, the research hypothesis is formulated as follows:

$\mathrm{H}_{3}$ : Top management support has a positive effect on independence.

\subsection{Top management support, indirectly, significantly affects the effectiveness of Internal Audit,} through competence

Management support plays a major role in an internal audit through competence. This is because all the determinants of internal audit effectiveness come from management support. This can be seen from the activity of hiring competent internal auditors and developing careers for internal auditors as a result of decisions made by top management, so it can be said that there is an influence between management support on competencies that affects the effectiveness of internal audit (Cohen \& Sayag, 2010). This is 
in line with research by Alzeban \& Gwilliam (2012) that states management support is a key driver of the perceived effectiveness of the internal audit function.

Based on this explanation, the research hypothesis is:

$\mathrm{H}_{4}$ : Top Management Support indirectly, significantly affects the effectiveness of Internal Audit, through competence.

\subsection{Top Management Support indirectly, significantly affects the effectiveness of Internal Audit, through Independence}

According to Cohen and Sayag (2010), internal auditors are given the freedom to conclude that their work is a decision made by top management. So that management support is very influential in influencing auditor independence. In line with Cohen and Sayag, Baharud-din et al (2014) also concluded that without support from management, an internal audit would not be independent and its scope of work and resources would be limited. This is in line with research by Alzeban \& Gwilliam (2012) that states management support is a key driver of the perceived effectiveness or otherwise of the internal audit function.

Based on this explanation, the research hypothesis is:

$\mathrm{H}_{5}$ : Top management support, indirectly, significantly affects the effectiveness of Internal Audit, through independence.

\subsection{The Effect of Competence on the Effectiveness of Internal Audit}

Internal audit competence plays an important role in making the internal audit function effective (IIA, 2006). The Indonesian government internal audit standard (SAIPI) also emphasizes that the role of an effective internal auditor/APIP can be achieved if it is carried out by a competent and professional auditor. Research on the influence of competence on the effectiveness of internal audit has been carried out by Salehi (2016), Baharud-din et al (2014), Drogalas et al (2015), Setyaningrum \& Kuntadi (2018), which show results in the form of competencies that make an important contribution to audit internal effectiveness. So, it can be concluded that with good internal auditors' competence in carrying out their duties, they will play a role in helping auditors formulate strategic recommendations for the organization to achieve its goals. From the explanation above, the hypothesis for the study is: $\mathrm{H}_{6}$ : Competence has a positive effect on the effectiveness of internal audit

\subsection{The Effect of Independence on the Effectiveness of Internal Audit}

Sawyer's (2009: 74) states that independence is an attitude that is free from any obstacles, this is shown by freely giving suggestions, recommendations, and statements without being restricted, unbiased, objectively, and having the freedom to reveal the real problem. In independence, everything is done not based on demand or influence from the executive or institution.

The International Standards for the Professional Practice of Internal Auditing (ISPPIA) explains that the independence of the internal audit is a key factor in achieving internal audit effectiveness.

Research by Salehi (2016) and also Alzeban \& Gwilliam (2014) shows that the independence of the internal audit contributes to the effectiveness of the internal audit. From this explanation, the research hypothesis is as follows:

$\mathrm{H}_{7}$ : Independence has a positive effect on the effectiveness of internal audit

\section{Research Method}

This research uses quantitative research methods. The data collection technique will be done in the form of using a survey method with a questionnaire. To prove the hypothesis s in this study, the verification analysis uses the component or variance-based Structural Equation Modeling (SEM) or other names Partial Least Square (PLS). Hypothesis testing in this study was carried out using the path coefficient, tvalue, and p-value. 
The unit of analysis in this research is internal audit in the public sector or the Indonesian government internal control apparatus (APIP) and the respondent for the variable management support, competence, and independence is the position of Assistant Inspector or Secretary or Regional Inspector, while for the variable of internal audit effectiveness, the respondents are the auditee of the internal audit.

\subsection{Population and Sample}

In this research, the target population of the research was 542 Internal Audit Units / APIP at the local government level. The sample determination referred to Hair's theory (2014), which is a sample size of at least 10 times the largest number of indicators of a variable. The largest indicator of a variable in this study is 5 , so the minimum number of samples is 50 samples. The researcher determined that the number of samples to be distributed by the research questionnaire was 55 APIP or $10.15 \%$ of the population. For sample selection, the stratified random sampling method was used. The grouping is divided based on the level of APIP capability by using the Regional APIP Capability level recap data from BPKP in 2019 so that there are 3 strata used, the number of samples taken based on each of these strata is determined proportionally with the formula:

$$
\mathrm{n}=\text { (population strata / total population) } \mathrm{x} \text { Number of samples specified }
$$

The details are as follows:

Table 1. Proportional Stratified Sampling

\begin{tabular}{|l|l|l|l|}
\hline $\begin{array}{c}\text { capability } \\
\text { level }\end{array}$ & $\begin{array}{c}\text { amount of } \\
\text { APIP }\end{array}$ & \multicolumn{1}{|c|}{$\begin{array}{c}\text { proportional } \\
\text { sample }\end{array}$} & rounding \\
\hline 1 & 74 & 7.51 & 7 \\
\hline 2 & 313 & 31.76 & 32 \\
\hline 3 & 155 & 15.73 & 16 \\
\hline total & $\mathbf{5 4 2}$ & $\mathbf{5 5}$ & $\mathbf{5 5}$ \\
\hline
\end{tabular}

Source: Data Processing (2020)

After obtaining the proportional sample, the population of each stratum was randomly selected using the excel application.

\subsection{Operationalization of Variables}

Top Management Support variable indicators are sourced from Cohen \& Sayag (2010), Tackie et al (2016), AAIPI (2014), BPKP (2015), Hailemariam (2014), and Alzeban \& Gwilliam (2014) with several adjustments, namely Recruitment competent employees, involvement in planning internal audit activities, management responses related to follow-up on audit findings and recommendations, strengthening commitments, and resource allocation for the internal audit department Competency indicators are sourced from Arens et al (2013), BPKP (2015), Kagaba (2018), Mihret \& Yismaw (2007), Baharud-din et al (2014), and Alzeban \& Gwilliam (2014) with several adjustments, namely as work experience in supervisory activities, educational qualifications, continuous development, professional qualifications. Independence indicators are sourced from Baharud-din et al (2014), Salehi (2016), BPKP (2015), Cohen \& Sayag (2010), Tackie et al (2016), and Alzeban \& Gwilliam (2014) with several adjustments, namely Independent Institutional Status, Reporting Relationships/Reporting levels, Interventions, Conflicts of Interest, Unlimited access to assets, information, and organizational unit personnel. Indicators of the effectiveness of internal audit come from Cohen \& Sayag (2010), BPKP (2015), AAIPI (2014), and Alzeban et al (2014) with some adjustments, namely the ability to find and provide audit recommendations that are useful to the organization, Ability to prevent errors, risks, and fraud, and the ability to provide added value to the organization. 


\section{Result and Discussion}

\subsection{Evaluation of Outer Model}

4.1.1 Convergent Validity Test

Table 2. Loading Factor

\begin{tabular}{|l|c|c|c|}
\hline \multicolumn{1}{|c|}{ Construct } & $\begin{array}{c}\text { Loading } \\
\text { Factor }\end{array}$ & $\begin{array}{c}\text { R } \\
\text { critical }\end{array}$ & $\begin{array}{c}\text { Criteria ( Loading } \\
\text { Factor > 0.5) }\end{array}$ \\
\hline COM1 <- Competence & 0.735 & 0.5 & Valid \\
\hline COM2 <- Competence & 0.705 & 0.5 & Valid \\
\hline COM3 <- Competence & $\mathbf{0 . 7 6 6}$ & 0.5 & Valid \\
\hline COM4 <- Competence & 0.753 & 0.5 & Valid \\
\hline EIA1 <- Internal_Audit Effectiveness & $\mathbf{0 . 8 7 2}$ & 0.5 & Valid \\
\hline EIA2 <- Internal_Audit Effectiveness & 0.762 & 0.5 & Valid \\
\hline EIA3 <- Internal_Audit Effectiveness & 0.739 & 0.5 & Valid \\
\hline IND1 <- Independence & $\mathbf{0 . 8 0 3}$ & 0.5 & Valid \\
\hline IND2 <- Independence & 0,700 & 0.5 & Valid \\
\hline IND3 <- Independence & 0.726 & 0.5 & Valid \\
\hline IND4 <- Independence & 0.8033 & 0.5 & Valid \\
\hline IND5 <- Independence & 0.725 & 0.5 & Valid \\
\hline TMS1 <- Top_Management Support & 0.782 & 0.5 & Valid \\
\hline TMS2 <- Top_Management Support & 0.767 & 0.5 & Valid \\
\hline TMS3 <- Top Management Support & 0.772 & 0.5 & Valid \\
\hline TMS4 <- Top_Management Support & $\mathbf{0 . 8 2 8}$ & 0.5 & Valid \\
\hline TMS5 <- Top Management Support & 0.789 & 0.5 & Valid \\
\hline SOurce: Data Processing(2020) & & & \\
\hline
\end{tabular}

Source: Data Processing (2020)

Table 2. shows the loading factor value for each construct of each variable. Based on this table, it can be seen that all loading factors are worth more than 0.5. So, it can be concluded that based on each construct in the study it has good validity. In the top management support variable, it is known that the most dominant indicator forming top management support is TMS4, namely the involvement of top management in planning APIP supervision activities with a loading factor value of 0.828. In the competency variable, it is known that the most dominant indicator that forms competence is COM3, namely Educational Qualification with a loading factor value of 0.766 . In the independence variable, it is known that the most dominant indicator forming independence is IND1, namely the independent institutional status with a loading factor value of 0.803 , and in the internal audit effectiveness variable, it is known that the most dominant dimension shaping the effectiveness of internal audit is EIA1, namely the ability to produce findings and Audit recommendations that are useful for organizations with a loading factor value of 0.872 .

\subsubsection{Discriminant Validity Test}

Table 3. Cross-Loading Discriminant Validity Test Value

\begin{tabular}{|l|r|r|r|r|}
\hline & $\begin{array}{c}\text { Top_Management } \\
\text { Support }\end{array}$ & $\begin{array}{c}\text { Internal_Audit } \\
\text { Effectiveness }\end{array}$ & Independence & \multicolumn{1}{c|}{ Competence } \\
\hline COM1 & 0.290 & 0.454 & 0.508 & $\mathbf{0 . 7 3 5}$ \\
\hline COM2 & 0.285 & 0.540 & 0.312 & $\mathbf{0 . 7 0 5}$ \\
\hline
\end{tabular}




\begin{tabular}{|c|c|c|c|c|}
\hline COM3 & 0.658 & 0.408 & 0.530 & 0.766 \\
\hline COM4 & 0.236 & 0.441 & 0.242 & 0.753 \\
\hline EIA1 & 0.397 & 0.872 & 0.517 & 0.548 \\
\hline EIA2 & 0.432 & 0.762 & 0.563 & 0.365 \\
\hline EIA3 & 0.330 & 0.739 & 0.377 & 0.557 \\
\hline IND1 & 0.316 & 0.545 & 0.803 & 0.224 \\
\hline IND2 & 0.705 & 0.444 & 0,700 & 0.648 \\
\hline IND3 & 0.342 & 0.452 & 0.726 & 0.468 \\
\hline IND4 & 0.191 & 0.490 & 0.803 & 0.331 \\
\hline IND5 & 0.166 & 0.311 & 0.725 & 0.254 \\
\hline TMS1 & 0.782 & 0.376 & 0.382 & 0.257 \\
\hline TMS2 & 0.767 & 0.402 & 0.277 & 0.338 \\
\hline TMS3 & 0.772 & 0.353 & 0.475 & 0.521 \\
\hline TMS4 & 0.828 & 0.386 & 0.508 & 0.627 \\
\hline TMS5 & 0.789 & 0.420 & 0.342 & 0.196 \\
\hline
\end{tabular}

Source: Data Processing (2020)

Based on Table 3, it can be seen that all indicators have a high correlation with their constructs compared to other constructs. It can be concluded that the research model has good discriminant validity in the discriminant validity of cross-loading.

Table 4. The value of Cronbach's Alpha and Composite Reliability

\begin{tabular}{|l|l|l|}
\hline Latent & Cronbach's Alpha & Composite Reliability \\
\hline Top_Management Support & 0.852 & 0.891 \\
\hline Internal_Audit Effectiveness & 0.702 & 0.835 \\
\hline Independence & 0.815 & 0.867 \\
\hline Competence & 0.729 & 0.829 \\
\hline
\end{tabular}

Source: Data Processing (2020)

Based on Table 4, it can be seen that there are latent constructs that have a Cronbach's alpha value of more than 0.7 , this indicates that the latent construct has good reliability. Also, the composite reliability value of all latent constructs has a value greater than 0.70 , this indicates that the latent construct has good reliability.

\subsection{The Structural Model Test (Inner Model)}

\subsubsection{R Square}

Based on test results with SmartPLS 3, the result of R Square as follows.

Table 5. R Square

\begin{tabular}{|l|l|l|}
\hline & R Square & Strong Relationship \\
\hline Internal Audit_Effectiveness & 0.496 & Moderate \\
\hline Independence & 0.272 & Weak \\
\hline Competence & 0.281 & Weak \\
\hline
\end{tabular}

Source: Data Processing (2020) 
From the results of Table 5, it can be seen that the R-Square for the variable of internal audit effectiveness is 0.496 , which means that top management support contributes 0.496 or $49.6 \%$ of the influence on the effectiveness of internal audit through competency and independence variables with moderate categories. While the remaining $50.4 \%$ is the influence of other factors that are not observed. R-Square for the variable independence by 0272 , which means that the top support management peaks contributing influence of 0.272 or $27.2 \%$ in the independence of the weak categories. While the remaining $92.8 \%$ is the influence of other factors that are not observed and the R-Square for the competency variable is 0.281 , which means that top management support contributes 0.281 or $28.1 \%$ to the weak category of competence. While the remaining $71.9 \%$ is the influence of other factors that are not observed.

\subsubsection{F Square}

Table 6. F Square

\begin{tabular}{|c|c|c|}
\hline Variable & Effect Size & Rating \\
\hline \multicolumn{3}{|c|}{ Competence } \\
\hline Top Management Support & 0.373 & Big \\
\hline \multicolumn{3}{|c|}{ Independence } \\
\hline Top Management Support & 0.391 & Big \\
\hline \multicolumn{3}{|c|}{ Effectiveness of Internal Audit } \\
\hline Top Management Support & 0.015 & Small \\
\hline Competence & 0.155 & Intermediate \\
\hline Independence & 0.162 & Intermediate \\
\hline
\end{tabular}

Source: Data Processing (2020)

Based on Table 6, shows that the top management support variable has a large category of influence in influencing the effectiveness of internal audit through competence and also through independence. Top management support variables have a small category of influence in influencing the effectiveness of internal audit through independence; the Competency variable has medium category influence in influencing internal audit effectiveness, and the independent variable has medium category influence in influencing internal audit effectiveness.

\subsubsection{Q-square Predictive Relevance}

Tabel 7. $Q^{2}$ Predictive Relevance

\begin{tabular}{|l|c|c|}
\hline \multicolumn{1}{|c|}{ Variable } & R Square & 1-R Square \\
\hline Internal Audit_Effectiveness & 0.496 & 0.504 \\
\hline Independence & 0.272 & 0.728 \\
\hline Competence & 0.281 & 0.719 \\
\hline $\mathrm{Q}^{2}=$ & $\mathrm{Q}^{2}=1-\left(1-\mathrm{R}_{1}{ }^{2}\right) *\left(1-\mathrm{R}_{2}{ }^{2}\right) *\left(1-\mathrm{R}_{3}{ }^{2}\right)=0.736$ \\
\hline Galat $=$ & \multicolumn{2}{|c|}{$\mathrm{Q} 2=100 \%-73.6 \%=26.4 \%$} \\
\hline
\end{tabular}

Source: Data Processing (2020)

Based on the results of the above calculations, it is known that the value of $\mathrm{Q}$ square is greater than 0 , this means that the observed values have been reconstructed well so that the model has predictive relevance. 


\subsubsection{Hypothesis Testing}

The magnitude of the significance value between the tested variables is presented in the form of the value contained in the arrow that connects one of the variables to the variable being the goal.

Figure 1. Significance Value (t-count)

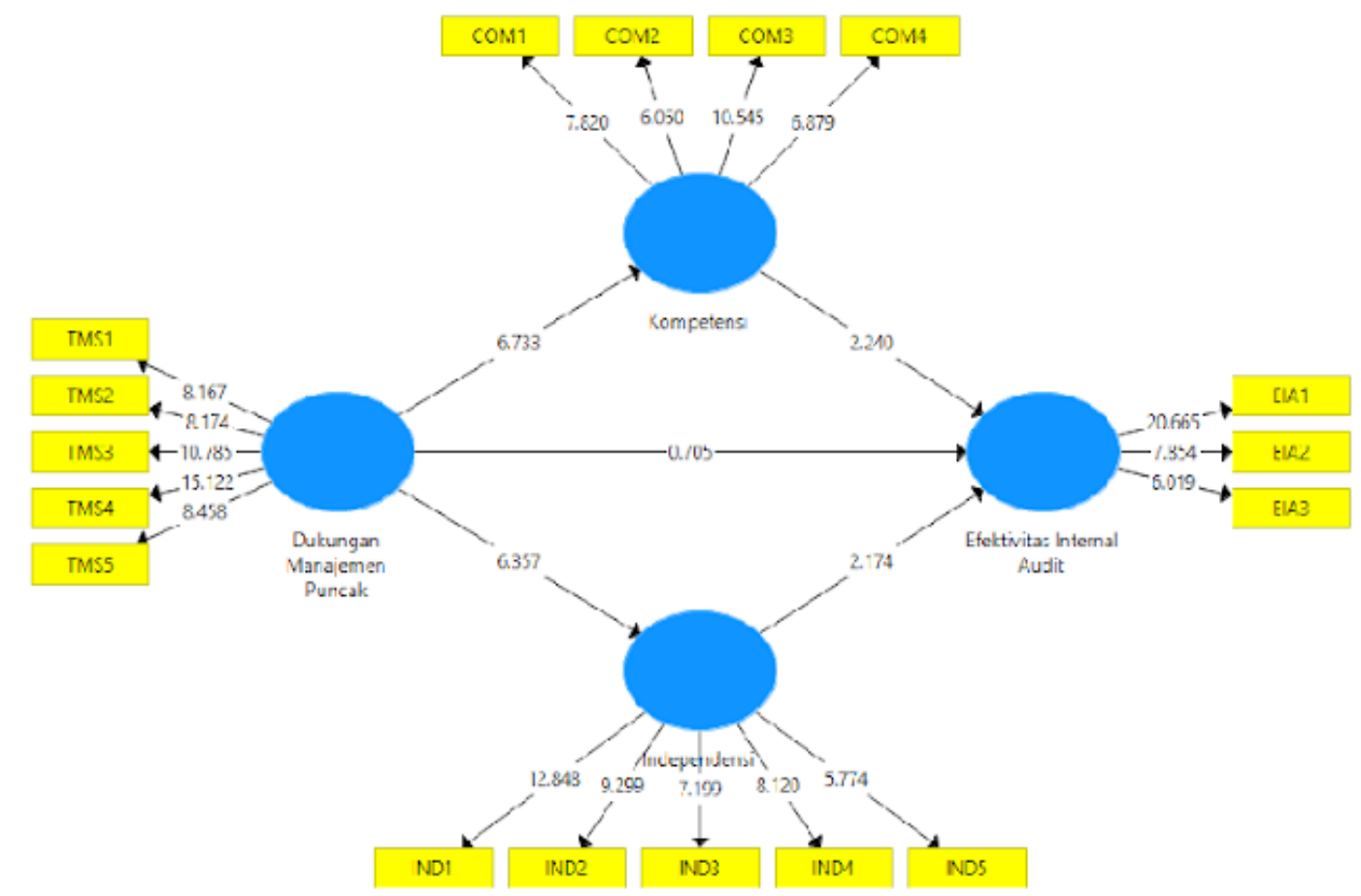

Source: Data processing output using SmartPLS (2020)

\section{a. Effect of Top Management Support on the Effectiveness of Internal Audit}

Table 8. Path Coefficient and Peak Management Support t-count to Internal Audit Effectiveness

\begin{tabular}{|c|c|c|c|c|}
\hline & $\begin{array}{c}\text { Original } \\
\text { Sample (O) }\end{array}$ & t-Statistics & p-value & Conclusion \\
\hline $\begin{array}{c}\text { Top Management Support for the } \\
\text { Effectiveness of Internal Audit }\end{array}$ & 0.109 & 0.705 & 0.481 & Thank H0 \\
\hline
\end{tabular}

Source: Data Processing (2020)

From the results of the table above, the Original Sample $(\mathrm{O})$ value is positive, namely 0.109 , indicating that the direction of influence between top management support on the effectiveness of internal audit is positive or unidirectional, meaning that if top management support increases, the effectiveness of internal audit will increase. The influence of top management support on internal effectiveness is not significant, with a $\mathrm{t}$-statistic value of 0.705 smaller than the $\mathrm{t}$ table or $0.705<1.96$, and a pvalue of 0.481 greater than alpha $5 \%(0.05)$. Thus, H 1 is rejected, meaning that top management support has no significant effect on the effectiveness of the internal audit. The results of this study are not in line with the research of Cohen and Sayag (2010), Alzeban \& Gwilliam (2014), Mihret \& Yismaw (2007), Baharud-din et al (2014), and Drogalas et al (2015) but the results of this study are in line with research by Tackie et al (2016) which shows the results that top management support has no significant effect on the effectiveness of the internal audit. 
It can be explained that directly top management support does not affect significantly the effectiveness of internal audit because top management influences the determinants of internal audit effectiveness to make internal audit effective, in line with the theory of Cohen \& Sayag (2010) which states that the determinants of effectiveness Internal audit come from management support, including hiring competent internal audit staff, developing internal auditors' careers, and ensuring the independence of the internal audit organization. However, based on the result show that if top management support increases, the effectiveness of internal audit will increase but not a significant effect.

\section{b. Effect of Top Management Support on Competence}

Table 9. Path coefficient and t-count of Top Management Support for Competence

\begin{tabular}{|c|c|c|c|c|}
\hline & $\begin{array}{c}\text { Original } \\
\text { Sample (O) }\end{array}$ & t-Statistics & p-value & Conclusion \\
\hline $\begin{array}{c}\text { Top Management Support for } \\
\text { Competence }\end{array}$ & 0.530 & 6,733 & 0,000 & Reject H0 \\
\hline
\end{tabular}

Source: Data Processing (2020)

From the results of Table above, the Original Sample $(\mathrm{O})$ value is positive, namely 0.530, indicating that the direction of influence between top management support on competence is positive or unidirectional, meaning that if top management support increases, competence will increase. The effect of top management support on significant competence, with a t-statistic value of 6.733 greater than the t table or 6.733> 1.96, and a p-value of 0.000 smaller than alpha 5\% (0.05). Thus, H 1 is accepted, meaning that top management support has a significant effect on competence. The results of this study indicate that the existence of top management support will increase the competence of internal audit. This result support on theory of AAIPI Internal Audit Standards (2014) and BPKP (2015) that there must be a commitment from stakeholders, one of which is top management support for improving APIP competence.

\section{c. Effect of Top Management Support on Independence}

Table 10. Path Coefficient and Top Management Support t-count of Independence

\begin{tabular}{|c|c|c|c|c|}
\hline & $\begin{array}{c}\text { Original } \\
\text { Sample (O) }\end{array}$ & t-Statistics & p-value & Conclusion \\
\hline $\begin{array}{c}\text { Top Management Support for } \\
\text { Independence }\end{array}$ & 0.521 & 6,357 & 0,000 & Reject H0 \\
\hline
\end{tabular}

Source: Data Processing (2020)

From the results of Table above, the Original Sample (O) value is positive, namely 0.521, indicating that the direction of influence between top management support on independence is positive or unidirectional, meaning that if top management support increases, independence will increase. The influence of top management support independence significantly, with a t-statistic value of 6.357 is greater than $t$ table or 6.357> 1.96, and the value of $p$-value of 0.000 is less than $5 \%$ alpha $(0: 05)$. Thus, H1 is accepted, meaning that top management support has a significant effect on independence. The results of this study indicate that the support of top management will increase the independence of internal audit. This result is in line with the theory from Baharud-din et al (2014) that without support from management, an internal audit would not be independent and its scope of work and resources would be limited. 
d. The Indirect Effect of Top Management Support on the Effectiveness of Internal Audit through Competence

Table 11. Path coefficient and t-count of Top Management Support Indirectly, on the Effectiveness of Internal Audit through Competence

\begin{tabular}{|c|c|c|c|c|}
\hline & $\begin{array}{c}\text { Original } \\
\text { Sample }(\mathbf{O})\end{array}$ & t-Statistics & p-value & Conclusion \\
\hline $\begin{array}{c}\text { Indirect top management support for } \\
\text { the effectiveness of internal audit } \\
\text { through competence }\end{array}$ & 0.193 & 2,027 & 0.043 & Reject H0 \\
\hline
\end{tabular}

Source: Data Processing (2020)

From the results of the table above, the Original Sample $(\mathrm{O})$ value is obtained which is positive, namely 0.193 , indicating that the direction of influence between top management support on the effectiveness of internal audit through competence is positive or unidirectional, meaning that if top management support increases, competence will also increase which will then increase the effectiveness of internal audits. The effect of top management support on the effectiveness of internal audit through significant competence, with a t-statistic value of 2.027 greater than the table or 2.027> 1.96, and a p-value of 0.043 which is smaller than alpha 5\% (0.05). Thus, H1 is accepted, meaning that top management support indirectly, significantly affects the effectiveness of internal audit, through competence.

The results of this study indicate that to make an internal audit effective, top management support must influence internal audit competence first so that top management's commitment to competence is needed to increase the effectiveness of the internal audit. This result also supports the theory of Cohen and Sayag (2010) said that there is an influence between management support on competencies that affects the effectiveness of internal audit, it is because of the activity of hiring competent internal auditors and developing careers for internal auditors as a result of decisions made by top management.

e. The Indirect Effect of Top Management Support on the Effectiveness of Internal Audit through Independence

Table 12. Path coefficient and t-count of Top Management Support Indirectly, on the Effectiveness of Internal Audit through Independence

\begin{tabular}{|c|c|c|c|c|}
\hline & $\begin{array}{c}\text { Original } \\
\text { Sample (O) }\end{array}$ & t-Statistics & p-value & Conclusion \\
\hline $\begin{array}{c}\text { Top management support indirectly the } \\
\text { effectiveness of internal audit through } \\
\text { independence }\end{array}$ & 0.185 & 2,005 & 0.046 & Reject H0 \\
\hline
\end{tabular}

Source: Data Processing (2020)

From the results of the table above, the Original Sample (O) value is obtained, which is positive, namely 0.185 , indicating that the direction of influence between top management support on the effectiveness of internal audit through competence is positive or unidirectional, meaning that if top management support increases, competence will also increase which will then increase. increase the effectiveness of the internal audit. The effect of top management support on the effectiveness of internal audit through significant competence, with a t-statistic value of 2.005 greater than the $t$ table or 2.005> 1.96, and p-value of 0.046 which is smaller than alpha 5\% (0.05). Thus, H1 is accepted, meaning that top management support indirectly significantly affects the effectiveness of internal audit through independence. 
The results of this study indicate that to make internal audit effective, top management support must influence the independence of internal audit first so that top management's commitment to internal audit independence is needed to increase the effectiveness of internal audit and also support the theory of Cohen \& Sayag (2010).

\section{f. Effect of Competence on the Effectiveness of Internal Audit}

Table 13. Path Coefficient and Competency t-count on the effectiveness of Internal Audit

\begin{tabular}{|c|c|c|c|c|}
\hline & $\begin{array}{c}\text { Original } \\
\text { Sample (O) }\end{array}$ & t-Statistics & p-value & Conclusion \\
\hline $\begin{array}{c}\text { Competence on Internal Audit } \\
\text { Effectiveness }\end{array}$ & 0.365 & 2,240 & 0.026 & Reject H0 \\
\hline
\end{tabular}

Source: Data Processing (2020)

From the results of the table above, the Original Sample $(\mathrm{O})$ value is positive, namely 0.365 , indicating that the direction of influence between competence on the effectiveness of internal audit is positive or unidirectional, meaning that if competence increases, the effectiveness of internal audit will increase. The effect of competence on internal effectiveness is significant, with a t-statistic value of 2.240 greater than the $t$ table or $2.240>1.96$, and a p-value of 0.026 which is smaller than alpha $5 \%$ (0.05). Thus, $\mathrm{H} 1$ is accepted, meaning that competence has a significant effect on the effectiveness of the internal audit. This is following the results of research by Salehi (2016), Baharud-din et al (2014), Drogalas et al (2015), Setyaningrum \& Kuntadi (2018) which state that competence has a positive effect on the effectiveness of the internal audit.

\section{g. Effect of Independence on the Effectiveness of Internal Audit}

Table 14. Path coefficient and t-count of Independence to the Effectiveness of Internal Audit

\begin{tabular}{|c|c|c|c|c|}
\hline & $\begin{array}{c}\text { Original } \\
\text { Sample (O) }\end{array}$ & t-Statistics & p-value & Conclusion \\
\hline $\begin{array}{c}\text { Independence of Internal Audit } \\
\text { Effectiveness }\end{array}$ & 0.355 & 2,174 & 0.030 & Reject H0 \\
\hline
\end{tabular}

Source: Data Processing (2020)

From the results of Table above, the Original Sample $(\mathrm{O})$ value is positive, namely 0.355 , indicating that the direction of the influence between independence on the effectiveness of internal audit is positive or unidirectional, meaning that if independence increases, the effectiveness of internal audit will increase. The effect of the independence of the internal effectiveness is significant, with a value of $t$ statistic of 2.174 is greater than $t$ table or $2.174>1.96$, and the value of p-value of 0.030 is less than $5 \%$ alpha (0:05). Thus, $\mathrm{H} 1$ is accepted, meaning that independence has a significant effect on the effectiveness of the internal audit. This is following the results of research by Salehi (2016) and Alzeban \& Gwilliam (2014) Salehi (2016), Baharud-din et al (2014), Drogalas et al (2015), Setyaningrum \& Kuntadi (2018) which state that independence affects positively on the effectiveness of the internal audit.

\section{Conclusion}

Based on the results of the analysis and discussion carried out in the previous chapter, it can be concluded that 1) top management support has no significant effect on the effectiveness of internal audit; 2) top management support has a significant effect on competence; 3) top management support has a significant effect on independence 4) top management support indirectly has a significant effect on the effectiveness of internal audit, through competence; 5) top management support indirectly significantly affects the effectiveness of internal audit through independence, 6) competence has a significant effect on the effectiveness of internal audit; 7) independence has a significant effect on the effectiveness of the internal audit. 
Also, can be seen the important indicators of each variable, namely the involvement of top management in planning APIP supervision activities for top management support variables, educational qualifications for competency variables, independent institutional status for the independent variables, and the ability to produce useful audit findings and recommendations. for the organization for the internal audit effectiveness variable.

It is hoped that the results of this study can be used as a consideration in determining policies by the Government which is currently encouraging the improvement of the effectiveness of internal audit in Indonesia, where the results show that with the support of top management to the competence and independence of internal audit, it will be able to encourage a more effective internal audit in carrying out its duties and functions.

Based on the results of the research, the authors suggest that researchers who will examine the effectiveness of internal audit should (1) conduct or expand research on government internal audit in ministries/agencies because the difference in work scope is quite different from internal audit at the local government level (2) add other independent variables such as the implementation of risk-based internal audit, use of information technology and other independent variables.

\section{References}

AAIPI. (2014). Standar Audit Intern Pemerintah Indonesia. Asosiasi Audit Internal Pemerintah Indonesia (AAIPI).

Adams, M. B. (1994). Agency Theory and the Internal Audit. Managerial Auditing Journal, 9(8), 812. https://doi.org/10.1108/02686909410071133

Alzeban, A., \& Gwilliam, D. (2014). Factors affecting the internal audit effectiveness: A survey of the Saudi public sector. Journal of International Accounting, Auditing, and Taxation, 23(2), 74-86. https://doi.org/10.1016/j.intaccaudtax.2014.06.001

Alzeban, A., \& Gwilliam, D. (2012). Perceptions of managers and internal auditors as to factors affecting the effectiveness of internal audit in the public sector context. In 10th European Academic Conference on Internal Audit and Corporate Governance (pp. 1-54).

Badara, M. S., \& Saidin, S. Z. (2013). The Journey so far on Internal Audit Effectiveness: a Calling for Expansion. International Journal of Academic Research in Accounting, Finance and Management Sciences, 3(3), 340-351. https://doi.org/10.6007/ijarafms/v3-i3/225

Badan Pemeriksa Keuangan Republik Indonesia. 2019. Ikhtisar Hasil Pemeriksaan Semester I Tahun 2019. Diunduh tanggal 16 Januari 2020 dari https://www.bpk.go.id/ihps

Baharud-din, Z., Shokiyah, A., \& Ibrahim, M. S. (2014). Factors that contribute to the effectiveness of internal audit in public sector. International Proceedings of Economics Development and Research, 70, 126.

BPKP. 2015. Peraturan Kepala Badan Pengawasan Keuangan dan Pembangunan Nomor 16 Tahun 2015 tentang Pedoman Teknis Peningkatan Kapabilitas Aparat Pengawasan Intern Pemerintah.

Cohen, A., \& Sayag, G. (2010). The Effectiveness of Internal Auditing: An Empirical Examination of its Determinants in Israeli Organisations. Australian Accounting Review, 20(3), 296-307. https://doi.org/10.1111/j.1835-2561.2010.00092.x

Drogalas, G., Karagiorgos T. \& Arampatzis K. (2015). Factors associated with Internal Audit Effectiveness: Evidence from Greece. Journal of Accounting and Taxation, 7(7), 113 - 122

Hailemariam, S. (2014). Determinants of internal audit effectiveness in the public sector, a case study in selected Ethiopian public sector offices (Doctoral dissertation, Jimma University).

Hair JF, Hult GTM, Ringle CM, Sarstedt M. 2014. A Primer on Partial Least Squares Structural Equation Modeling (PLS-SEM). Los Angeles: Sage. 
Institute of Internal Auditors (IIA). (2006). The role of auditing in public sector governance. Florida: IIA. Retrieved from: www.theiia.org/download.cfm?file $=3512$

Jensen, M. C., \& Meckling, W. . (1976). Theory of The Firm: Managerial Behavior, Agency Cost, and Ownership Structure. Journal of Financial Economics 3.

Julius Kagaba, Dr. Patrick Mulyungi. (2018). Determinants of Internal Audit Effectiveness of Public Sector; A Case Study Rwanda Revenue Authority. International Journal of Science and Research (IJSR) Volume 7 Issue 11. 617 - 620

Menteri Dalam Negeri. (2018). Kepmendagri Nomor 118-8840 Tahun 2018 Tentang Penetapan Peringkat dan Status Kinerja Penyelenggaraan Pemerintahan Daerah Secara Nasional Tahun 2017.

Mihret, D. G., \& Yismaw, A. W. (2007). Internal audit effectiveness: An Ethiopian public sector case study. Managerial Auditing Journal, 22(5), 470-484.

Salehi, T. (2016). Investigation factors affecting the effectiveness of internal auditors in the company: Case study Iran. Review of European Studies, 8 (2), 224-235.

Sawyer, Lawrence B., et.al. (2009). Audit Internal Sawyer Edisi 5 Buku 1. Jakarta: Salemba Empat.

Setyaningrum, D., \& Kuntadi, C. The Effect of Competence, Independence, Audit Work, and Communication on the Internal Audit Effectiveness.

Syarif, La Ode Muhammad. 2018. KPK pengawas internal belum efektif mencegah korupsi, diakses melalui www.republika.co.id/berita/nasional/hukum/18/04/17/p7bujq428

Tackie, G., Marfo-Yiadom, E., \& Achina, S. O. (2016). Determinants of internal audit effectiveness in decentralized local government administrative systems. International Journal of Business and Management, 11(11), 184.

Tugiman, Hiro. 2006. Standar Profesional Audit Internal. Yogyakarta : Kanisius.

\section{Copyright Disclaimer}

Copyright for this article is retained by the author(s), with first publication rights granted to the journal. 